\title{
THE TITLE OF PHILOSTRATUS' LIFE OF APOLLONIUS OF TYANA
}

\author{
GERARD BOTER \\ VU University Amsterdam*
}

\begin{abstract}
The title of Philostratus' Life of Apollonius of Tyana as it stands in all editions since Kayser's 1844 edition,

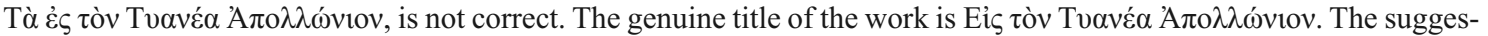
tion by Ewen Bowie, that the title of the work characterizes it as a novel, must therefore be dismissed. The meaning of the title is ambiguous: it means both 'About Apollonius of Tyana' and 'In honour of Apollonius of Tyana'. This ambiguity may very well have been intended by Philostratus.
\end{abstract}

Keywords: Philostratus, Apollonius of Tyana, book title, literary genre, ambiguity

The modern title of Philostratus' Life of Apollonius of Tyana ${ }^{1}$ (henceforward VA) does not correspond to the Greek title which has been current since Kayser's critical edition of 1844, namely Tà

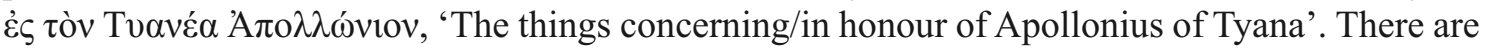
two issues concerning the title, namely the function of the article Tó and the meaning of the preposition $\dot{\varepsilon} \zeta$. In the first place, I will give a brief status quaestionis of the discussion on the title. Next, I will demonstrate that the article Tó does not belong to the original title. Then I will show that the absence of the article has consequences for the interpretation of the title; in particular, I will suggest that the absence of the article reinforces the encomiastic interpretation ('in honour of') of the preposition $\dot{\varepsilon} \varsigma$.

\section{Status quaestionis}

It is fitting to start an overview of the different interpretations of the title with Ewen Bowie's statement on the title of VA (Bowie (1978) 1665), if only because he attaches so much value to the

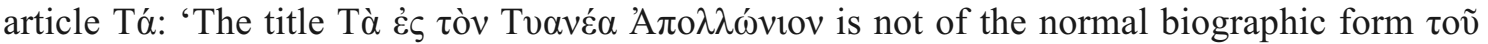

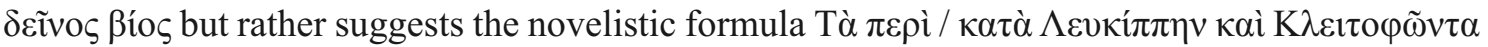
etc'. In a later publication with the telling title 'Philostratus: writer of fiction' (Bowie (1994) 189) he states: 'More diagnostic of the novel might be the form of the title - not The Life of Apollonius but The Stories of Apollonius of Tyana, like a novelist's The Story of Chaereas and Callirhoe'. ${ }^{2}$

Bowie apparently takes $\dot{\varepsilon} \zeta$ as an equivalent of $\pi \varepsilon \rho i ́$ and $\kappa \alpha \tau \alpha$, and in this respect he is followed by many scholars who do not share Bowie's opinion on the novel-like character of the title. Thus Hägg (2012) 319 renders the title as "“Things concerning ...", that is, "On Apollonius of Tyana". 3 Others interpret the preposition $\dot{\varepsilon} \zeta$ as encomiastic, 'in honour of'. Thus Phillimore's English translation (1912) bears the title In Honour of Apollonius of Tyana. ${ }^{4}$

* g.j.boter@vu.nl. I wish to thank Jaap-Jan Flinterman for his stimulating remarks and valuable suggestions and Nina King for correcting my English. I also thank this journal's anonymous reviewers.

1 This is the current title in English. Titles in other languages are equivalent to the English title: Vie d'Apollonius (for example des Places (1986) 38), Vita di Apollonio di Tiana (for example del Corno (1978)) and Das Leben des Apollonios von Tyana (for example Mumprecht (1983)).

2 Bowie's suggestion is accepted by Keulen (2006)
182. Independently from Bowie, del Corno (1978) 2728 relates the title of $V A$ to the titles of the novels.

3 Hägg ((2012) 319) remarks that the title is 'notoriously vague'. See also Hägg (2004) 387. Jones (2005) 3, n. 1 states: 'There is no need to assume that the proposition es implies a favorable account, "in honor of": $c f$. e.g. I 3.2, where es ton Apollonion surely means no more than "about Apollonius"; $c f$. Flinterman (2009) 155, n.1.

${ }^{4}$ Des Places (1986) translates the title of Eusebius'

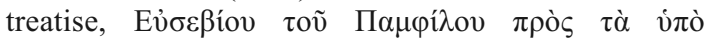

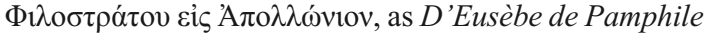


So there are roughly speaking three different labels attached to the title: novel (Bowie, del Corno, Keulen), biography or, less specifically, report of life and works (Jones, Flinterman) and encomium (Phillimore, des Places, Anderson, Swain, Whitmarsh, Robiano). ${ }^{5}$ Yet others again (Gyselinck (2008); Hägg (2012)) draw attention to the ambiguous status of the work, which is reflected in the title. ${ }^{6}$ But before going more deeply into the meaning of the title let us now study its actual form.

\section{The form of the title}

Kayser (1844) VIII states the following with regard to the title of $V A$ : 'Liber ab ipso Philostrato

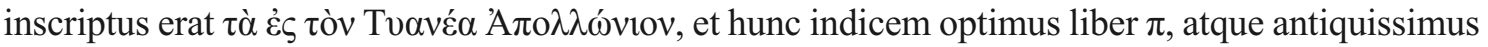

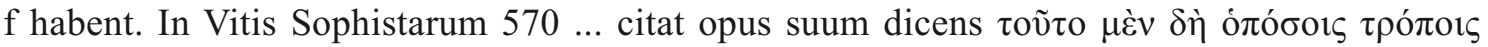

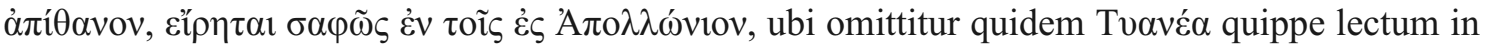

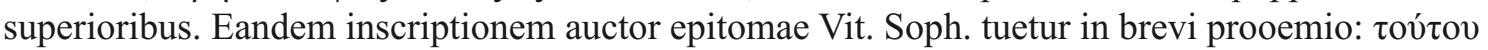

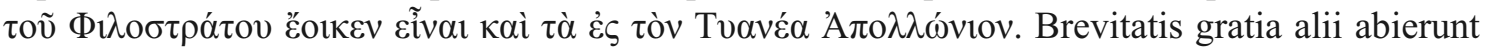

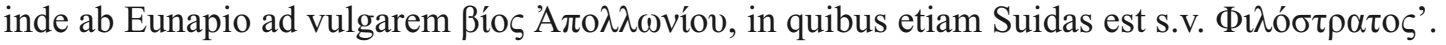

In the first place, it should be pointed out that Kayser's report of the mss readings is wrong in

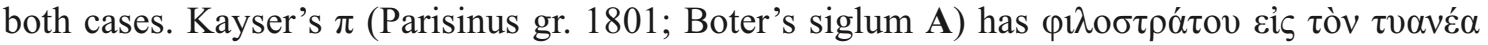

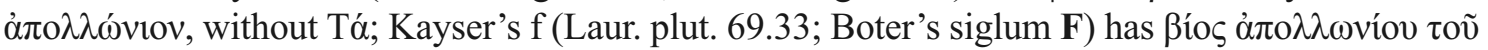

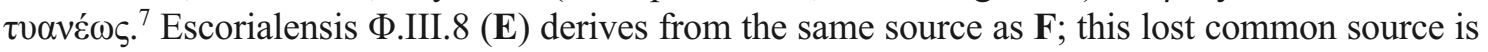

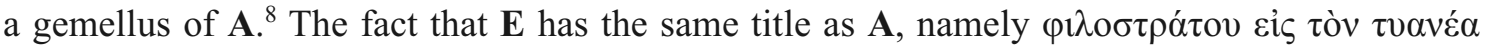
$\dot{\alpha} \pi \mathrm{\alpha} \lambda \lambda \omega \dot{v} v i o v$, proves that the archetype must have had this title as well. From Book 2 on all mss,

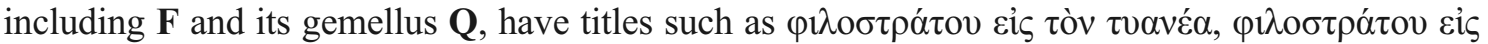

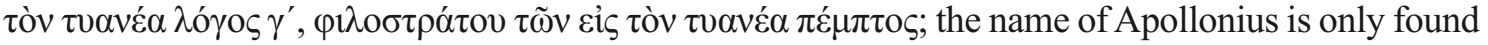

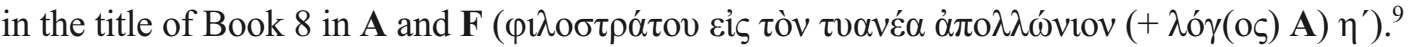

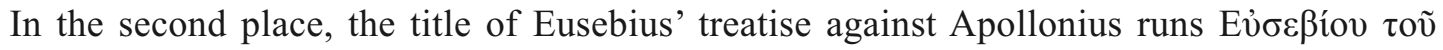

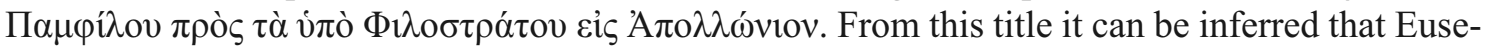
bius' copy of $V A$ had the same title as the archetype of the medieval tradition. This title is also

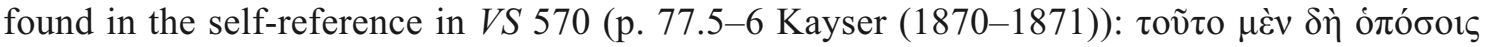

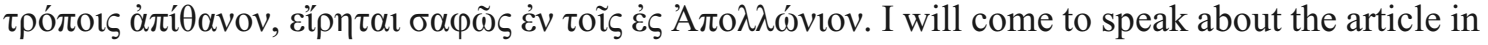
Eusebius and in the VS passage later on.

contre les écrits de Philostrate en l'honneur d'Apollonius. Similarly Anderson (1986) 121; Swain (1999) 157, n.1; Robiano (2001) 637; Whitmarsh (2001) 225, n.170. Robiano (2001) 638 states that 'il semble que le texte philostratéen connaisse parfaitement l'usage de cette préposition pour signifier sans aucun doute possible un éloge'.

${ }^{5}$ Reardon (1971) 189 combines the first and the third approach without, however, claiming that the novellike character of $V A$ is already apparent from the title: ' $L a$ Vie d'Apollonius de Tyane - plus exactement En l'honneur d'Apollonius de Tyane - est presque un roman'. Billault (2000) 51 sits on the fence. On the one hand, he states that the title "signifie litteralement Les choses relatives à Apollonios de Tyane et le mot "vie" n'y figure pas. Le livre d'Apollonios serait plus exact, malgré une légère ambiguïté'. But on the other hand, he sympathizes with Reardon's translation of the title, 'qui rend bien compte $\mathrm{du}$ caractère encomiastique du livre, même si elle s'éloigne un peu de la lettre du texte grec' (51, n.13).

${ }^{6}$ Gyselinck (2008) 3-5 wittily argues that a bibliothecarian aiming at clarity would be compelled to buy some 20 copies of the work and put them under the headings 'biography', 'travel literature', 'philosophy', 'history' and so on. Hägg (2012) 319-20 argues that the vague title 'leaves him the possibility of combining freely alternating between or fusing - a number of approaches to his subject, as we shall presently see exemplified in the text: apology, hagiography, biography, travelogue, documentary, fiction, paradoxography, political pamphlet, philosophical treatise, religious protreptic ...'. See also Francis (1998).

${ }^{7}$ F can be consulted at http://teca.bmlonline.it/Image Viewer/servlet/ImageViewer?idr=TECA0000830199\&k eyworks=plut.69.33\#page/1/mode/1 up (accessed 24 June 2015).

${ }^{8}$ For the textual tradition of $V A$ see Boter (2009; 2014). The fourth primary ms. of $V A$, Vaticanus Pal. gr.

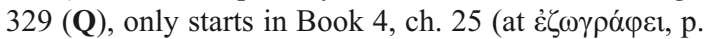
144.27 Kayser (1870-1871)), the preceding part of the work having got lost. $\mathbf{Q}$ is a gemellus of $\mathbf{F}$. See fig. 1 for a slightly simplified stemma of $V A$.

9 The word $\lambda$ óyos here is not to be regarded as forming part of the title: it equals our 'Book'. 


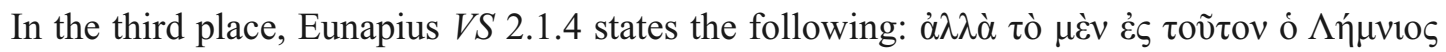

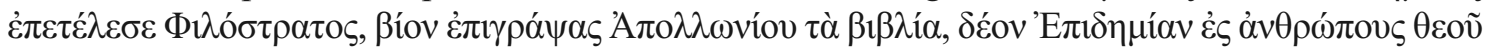

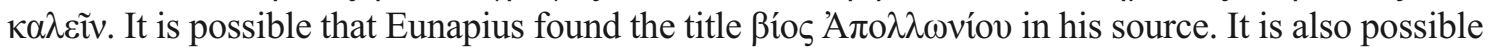
that he introduced this title himself. The point he wants to make is that Philostratus should have

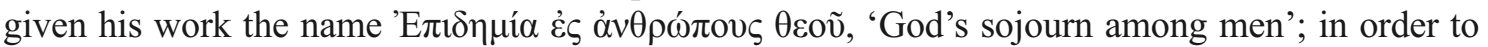

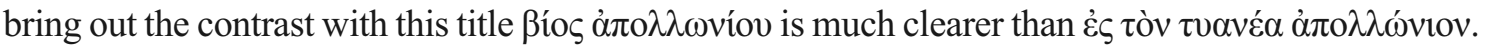

In the fourth place, two 'codices' in Photius' Bibliotheca, 44 and 241, are devoted to $V A$. The

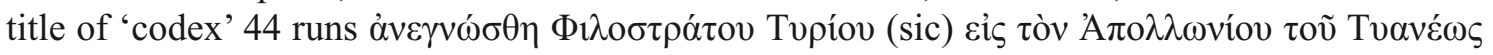

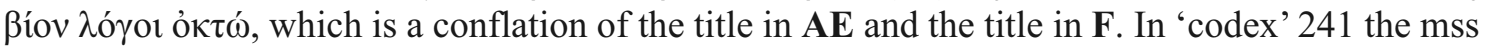

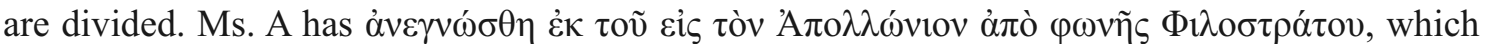

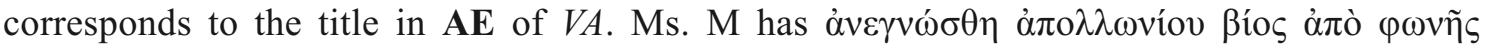
$\Phi 1 \lambda o \sigma \tau \rho \alpha ́ \tau o v$, which is close to the title of $V A$ in $\mathbf{F}$. Now Photius' source is a gemellus of the common ancestor of $\mathbf{F}$ and $\mathbf{Q}$. Because of the divergencies in Photius and because the titles of

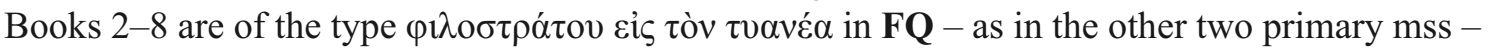

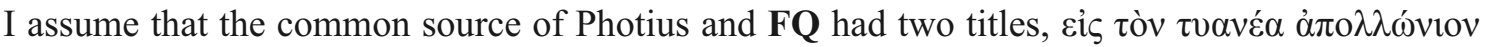

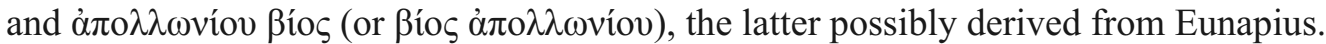

Finally, the Suda has the same title as F: see for instance $\kappa 2341 \dot{\omega} \varsigma \lambda \dot{\varepsilon} \gamma \varepsilon 1$ Фı $\lambda$ ó $\tau \tau \rho \alpha \tau o \varsigma$ o

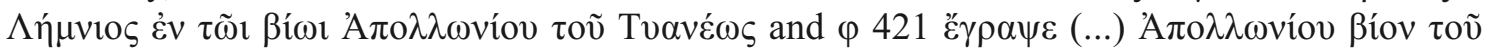

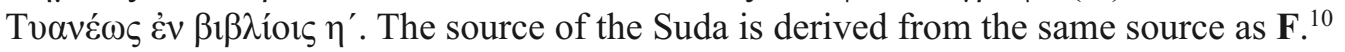

To sum up: Philostratus in the self-reference in $V S$, Eusebius in the title of his treatise and the

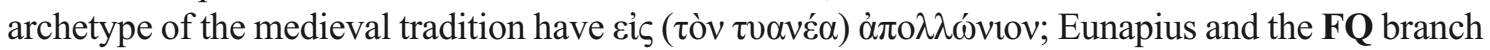

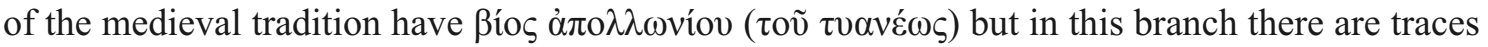
of the other title as well, namely in Photius and in the titles of Books 2-8 in FQ (which coincide

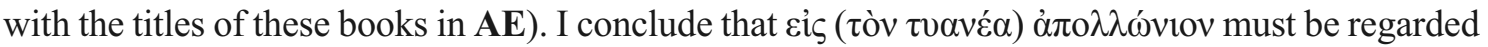

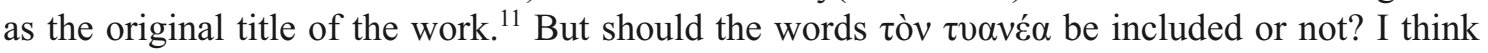
they should. As to the omission of the words in VS, Kayser rightly remarks: "ubi omittitur quidem Tvavé $\alpha$ quippe lectum in superioribus'. ${ }^{12}$ Because $\tau o ̀ v ~ \tau v \alpha v \varepsilon ́ \alpha$ had already been mentioned a few lines before it would be cumbersome to repeat it in the reference to $V A \cdot{ }^{13}$ As to the title of Eusebius'

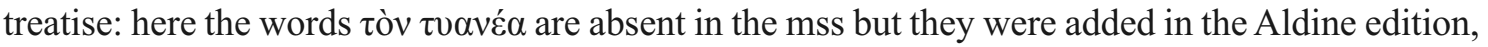

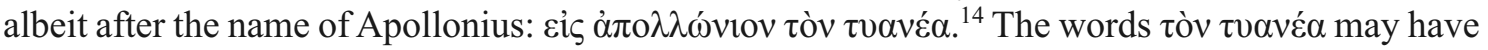
fallen out in Eusebius' source or in the course of the transmission of Eusebius' treatise, but I think

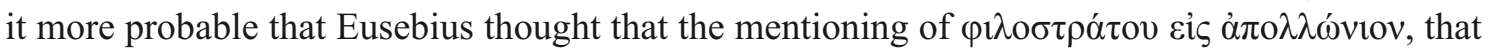
is, author with short title, would be sufficient for his readers to identify the work. ${ }^{15}$

\footnotetext{
${ }^{10}$ For a discussion of the stemmatical position of Photius and Suda, see Boter (2014) 38-45.

11 With regard to the form of the preposition it should be noted that in the title all witnesses have $\varepsilon i \zeta$, not $\dot{\varepsilon} \varsigma$. The form ei $\zeta$ is also found in all mss in the titles of Books 2-8. On the other hand, there are many places in $V A$ where the witnesses have $\dot{\varepsilon} \varsigma$. I think it is best to print everywhere the form as given in the transmission and not to strive for consistency in such matters. We simply cannot tell whether authors themselves intended to be consistent in this respect.

12 The full passage runs as follows: $\dot{\varepsilon} \rho \alpha \sigma \theta \tilde{\eta} v \alpha \iota \tau \tilde{\eta} \varsigma$

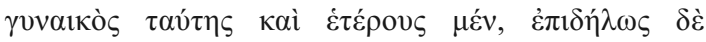

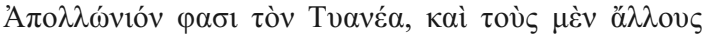

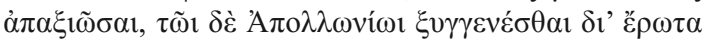

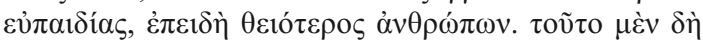

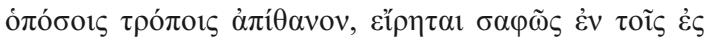

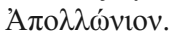

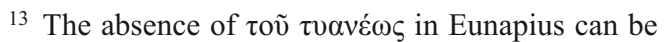
explained in the same way as its absence in Philostratus' self-reference in VS: in Eunapius too the name Apollonius with the toponym had already been mentioned a few

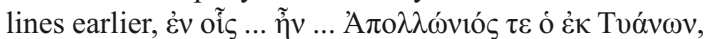

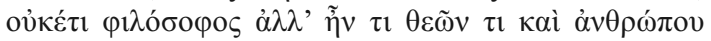

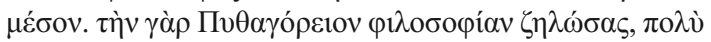

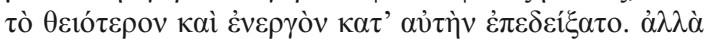
$\tau$

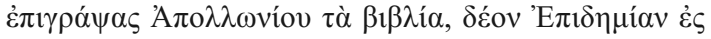
$\dot{\alpha} v \theta \rho \omega ́ \pi \mathrm{ov \varsigma} \theta \varepsilon \circ \tilde{v} \kappa \alpha \lambda \varepsilon \tilde{v}$.

14 Des Places wrongly states in his apparatus that the words were added by Kayser.

15 An analogous argument can be developed with regard to the absence of $\tau$ ov $\tau v \alpha v \varepsilon ́ \omega \varsigma$ in Photius: the combination of the author's name, Philostratus, and the short title $\dot{\alpha} \pi \mathrm{\alpha} \lambda \lambda \omega v$ vío ßíos is sufficient to identify the work. For a modern parallel of such an abbreviated title 
Let us now turn to the article Tá which precedes the title in the modern editions of $V A$ but which is absent from the mss A and E. As we have already seen, Kayser argues that Philostratus'

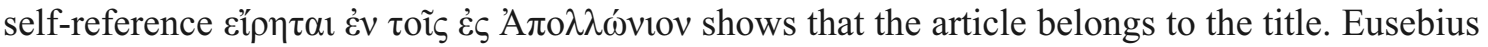

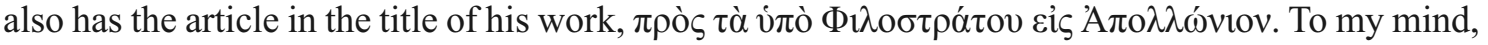
the article does not belong to the original title. The strongest argument in favour of this thesis is the absence of the article in A and E. Secondly, in Photius' 'codex' 44 the title is $\alpha v \varepsilon \gamma v \omega \sigma \sigma \theta \eta$

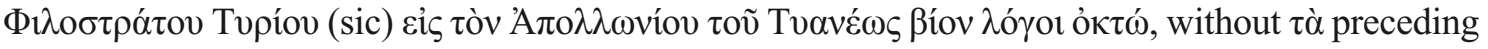

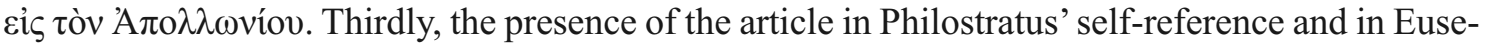
bius does not constitute an argument in favour of adding it to the title but should be explained in a different way.

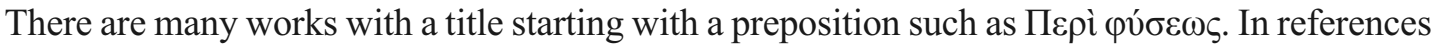
to a work with such a title the addition of the definite article before the title is indispensable, either

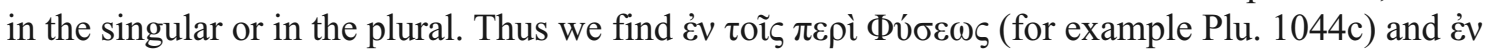

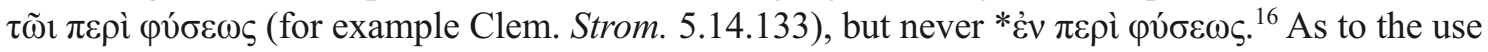
of the article preceding a title starting with $\pi \varepsilon \rho i$ it is interesting to have a look at Galen 18a.199

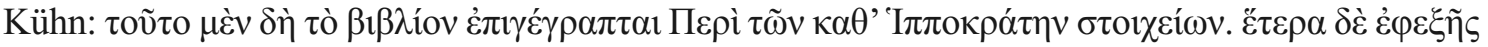

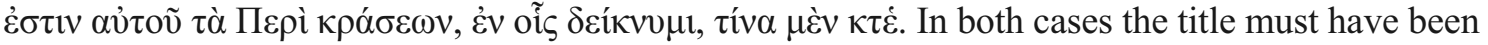
Пepi ..., without the article. When the title forms part of the running text Galen adds the article. ${ }^{17}$ This satisfactorily explains the presence of the article in the reference in the epitome of VS: $\tau$ ovi $\tau$ ov

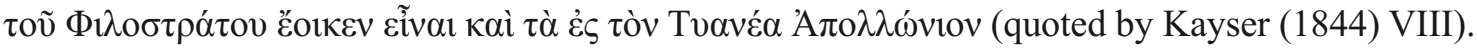

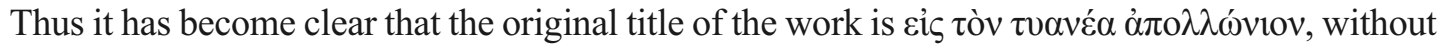
the article.

\section{The meaning of the title}

Now that we have established the form of the title we can turn to its meaning. In the first place we can conclude that the absence of Tó from the title refutes Bowie's claim that the title is meant to evoke associations with the novel. ${ }^{18}$

one might think of Goethe's Die Leiden des jungen Werthers, which is usually referred to as Goethe's Werther. For curiosity's sake I will briefly discuss the history of the title in the editions. The editio princeps by Aldus

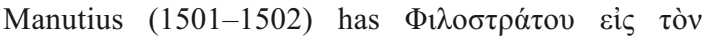

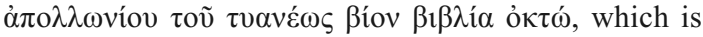
rendered in Latin as Philostrati de vita Apollonii Tyanei libri octo. The same title is also found in the editions by Morel (1608) and Olearius (1709); the latter has Tyanensis instead of Tyanei. This title is the same as the one in Photius' 'codex' 44 and I assume that Aldus took the title from Photius' Bibliotheca. Laur. plut. 69.26, which is the source of the Aldine edition, does not have any title; the title should have been added by the rubricator but this was never done. In the year 1501 Photius' Bibliotheca was not yet available in print but the Marcian library already possessed a number of mss of the work I therefore assume that Aldus consulted one of these mss. The title in the Aldine edition stood as the basis of the title Vita Apollonii as it is used nowadays. It is also reproduced in the early translations into vernacular languages, such as Baldelli's Della vita di Apollonio Tianeo (1549) and de Vigenère's translation De la vie d'Apollonius Thyaneen (1611). The title introduced by Kayser in 1844,

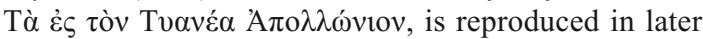
editions such as Westermann (1849), Conybeare (1912) and Mumprecht (1983). Jones, in his Loeb edition which replaces the one by Conybeare, states: 'Philostratus may have entitled the work On Apollonius of Tyana, but in general form and structure it is a biography, and far the longest that survives from antiquity' (Jones (2005) 3). The title page preceding Book 1 has 'The Life of Apollonius of Tyana', but Jones does not add any Greek title.

${ }^{16}$ Editors are not unanimous in their choice of which word should be written with a capital. See for instance:

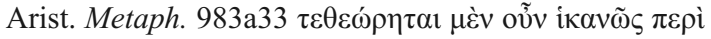

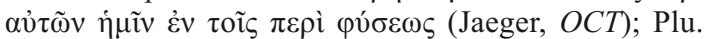

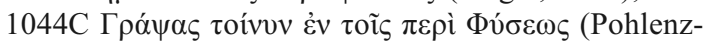
Westman, Teubner); Them. in de An., CAG 5.3, p. 46

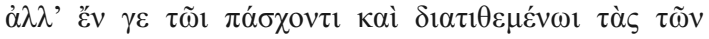

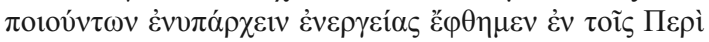

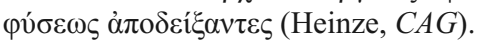

17 See also, for example, Galen 6.770 Kühn vं $\pi \dot{\varepsilon} \rho \tilde{\omega} v$

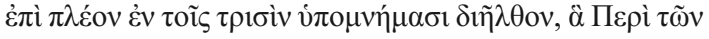

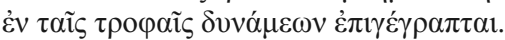

18 With regard to the titles of the novels to which Bowie refers one might also wonder whether these titles started with Tó. For instance, the ms. of Chariton's novel has the heading Xapí $\omega v$ os 'A

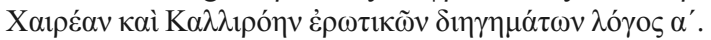
(On the basis of the reference in the papyrus and the subscription of the work itself, Reardon (2004) prints the 
We have already seen that the preposition sic is interpreted in two ways: the neutral 'on' and the encomiastic 'in honour of'. I have investigated the use of the preposition $\dot{\varepsilon} \varsigma / \varepsilon \dot{\varepsilon} \zeta$ in titles and references to works or passages of works.

The use of Eis in the sense of 'in honour/praise of' is regular in the titles of hymns, encomia

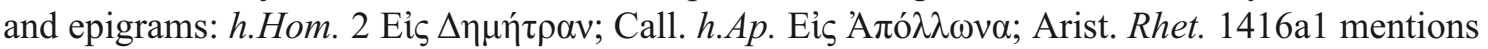

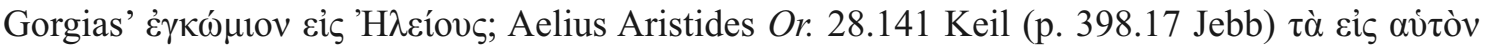

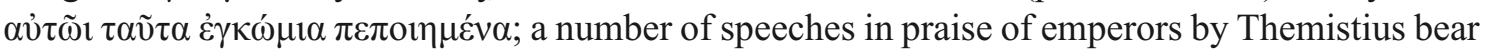

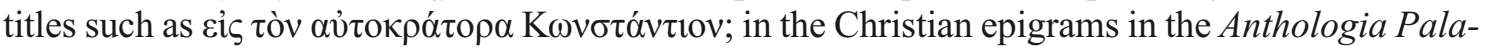

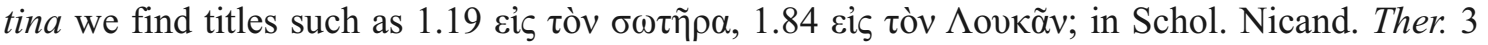

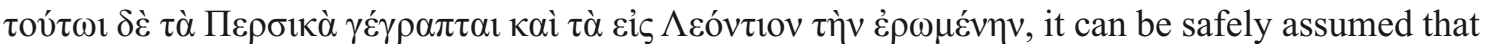
Ei ̧ has a positive sense. Robiano (2001) 638, n.5, quotes some instances of the encomiastic use of

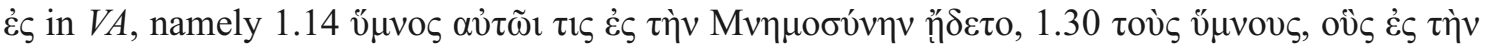

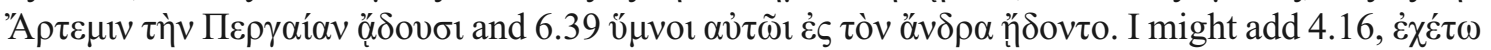

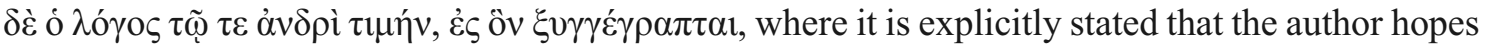
that the work will bring honour to Apollonius ( $\dot{\varsigma} \varsigma$ öv $\xi v \gamma \gamma \varepsilon \dot{\varepsilon} \rho \alpha \pi \tau \alpha \iota) .{ }^{19}$

Exceptionally, eic can also have the opposite meaning to 'in honour of', namely 'against', as

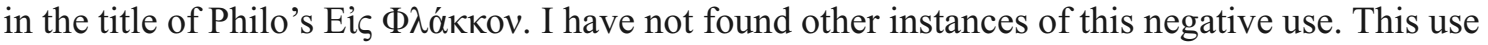
is exactly similar to Latin in + acc., as In Verrem. eis is regular in titles of commentaries; see for

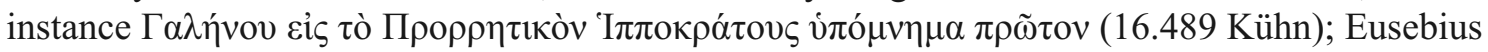

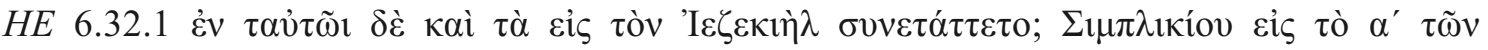

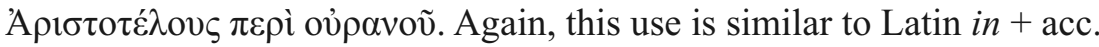

Pausanias very often uses $\dot{\varepsilon} \zeta$ in the neutral sense 'about'. Here are some instances: 3.2.3 $\varepsilon$ ' $\tau \varepsilon \sigma 1$

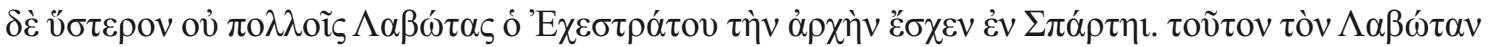

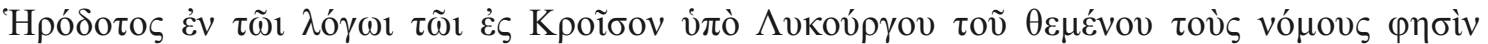

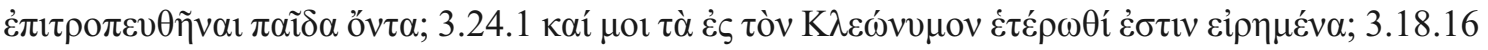

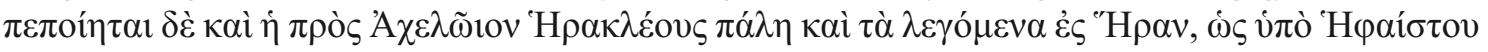

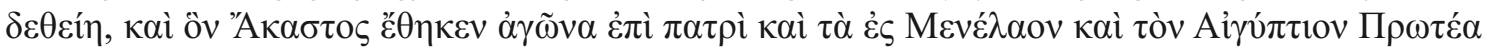

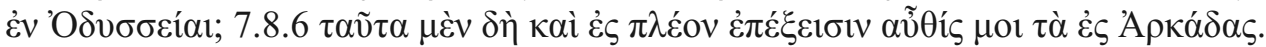

So we see that $\dot{\varepsilon} \varsigma / \varepsilon i \varsigma$ can be used in both a positive and a neutral sense (and sporadically in a negative sense). When used of persons in titles it almost always has a positive connotation; when used in running text (as in Pausanias) it usually has a neutral sense.

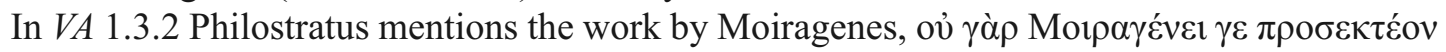

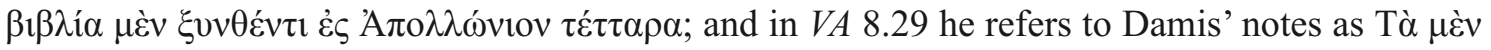

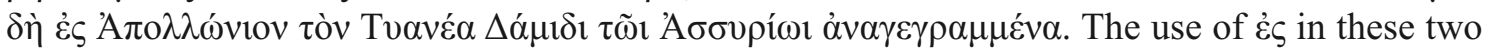
passages may be an echo of the title which Philostratus gave to his own work; alternatively (or rather, simultaneously: see below) these cases may be instances of $\dot{\varepsilon} \varsigma$ in the sense of 'about' which occurs so frequently in running text in Pausanias. ${ }^{20}$

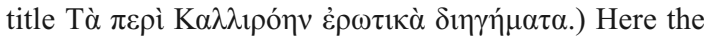
article $\tau \tilde{\omega} v$ belongs to $\delta \imath \gamma \eta \mu \alpha ́ \tau \omega v$, whereas in Tà $\dot{\varepsilon} \varsigma \tau$ òv Tvavé $\alpha$ A $\pi$ o $\lambda \lambda \omega$ viov there is no substantive to which the article belongs; further, $\tau \tilde{\omega} \nu \delta \eta \eta \gamma \eta \mu \alpha ́ \tau \omega \nu$ in its turn depends on $\alpha$ ', 'Book One'. By the same token, in the

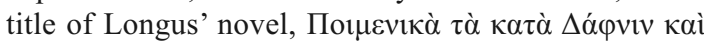

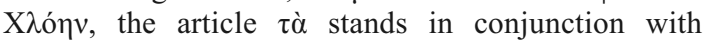

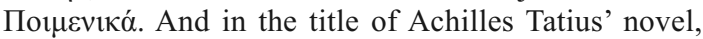

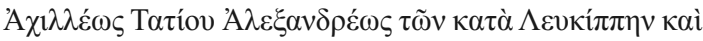
$\mathrm{K} \lambda \varepsilon 1 \tau$ $\varphi \tilde{\omega} \nu \tau \alpha \alpha^{\prime}$, the article in the genitive is necessary to make the whole title depend on $\alpha$ ', 'Book One'; $c f$. what I have said above about the addition of the article

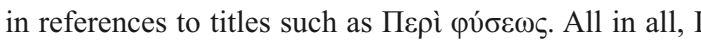

think that, for example, the title of Chariton should rather

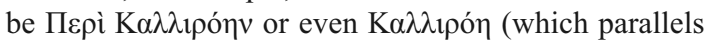
titles such as Xenophon's 'A $\gamma \eta \sigma i ́ \lambda \alpha \zeta$ ) than the title with the article we find in our editions.

19 See also Phillimore (1912) xvii: ‘A Hymn was

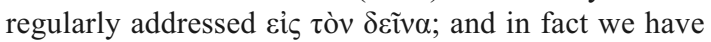
exactly our title in the Apollonius itself, [1.30 (p. 32.15

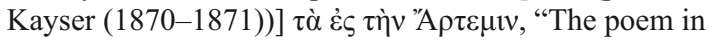
honour of Artemis"'. Of course, Phillimore wrongly believed that the article belongs to the title of $V A$.

${ }^{20}$ So Jones (2005) 3, n.1 (quoted above, n.3) on the former passage. 
The absence of the article Tó from the title reinforces the encomiastic interpretation of the title,

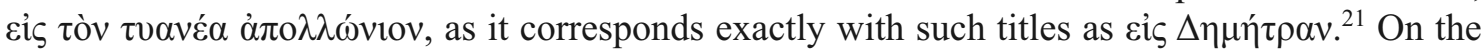
other hand, we have seen that the preposition can have a neutral meaning. With regard to the title, Hägg (2012) 319 states: 'But vagueness is no doubt the author's very intention'; Swain (1999) 157, n.1 renders the preposition $\varepsilon i \varsigma$ as 'relating to/in honour of' ${ }^{22}$ I very much sympathize with Swain's rendering, which suggests right from the start that the work is both an encomium ('in honour of') and an objective report ('relating to'). ${ }^{23}$ I do not know of a preposition in any current modern language which covers the two meanings of eis simultaneously, but if a choice has to be made - and this is inescapable because double renderings are inadmissible in translations - I would support Swain's choice, which becomes clear from the title of his article, 'Defending Hellenism: Philostratus, In Honour of Apollonius'. Traduttore traditore.

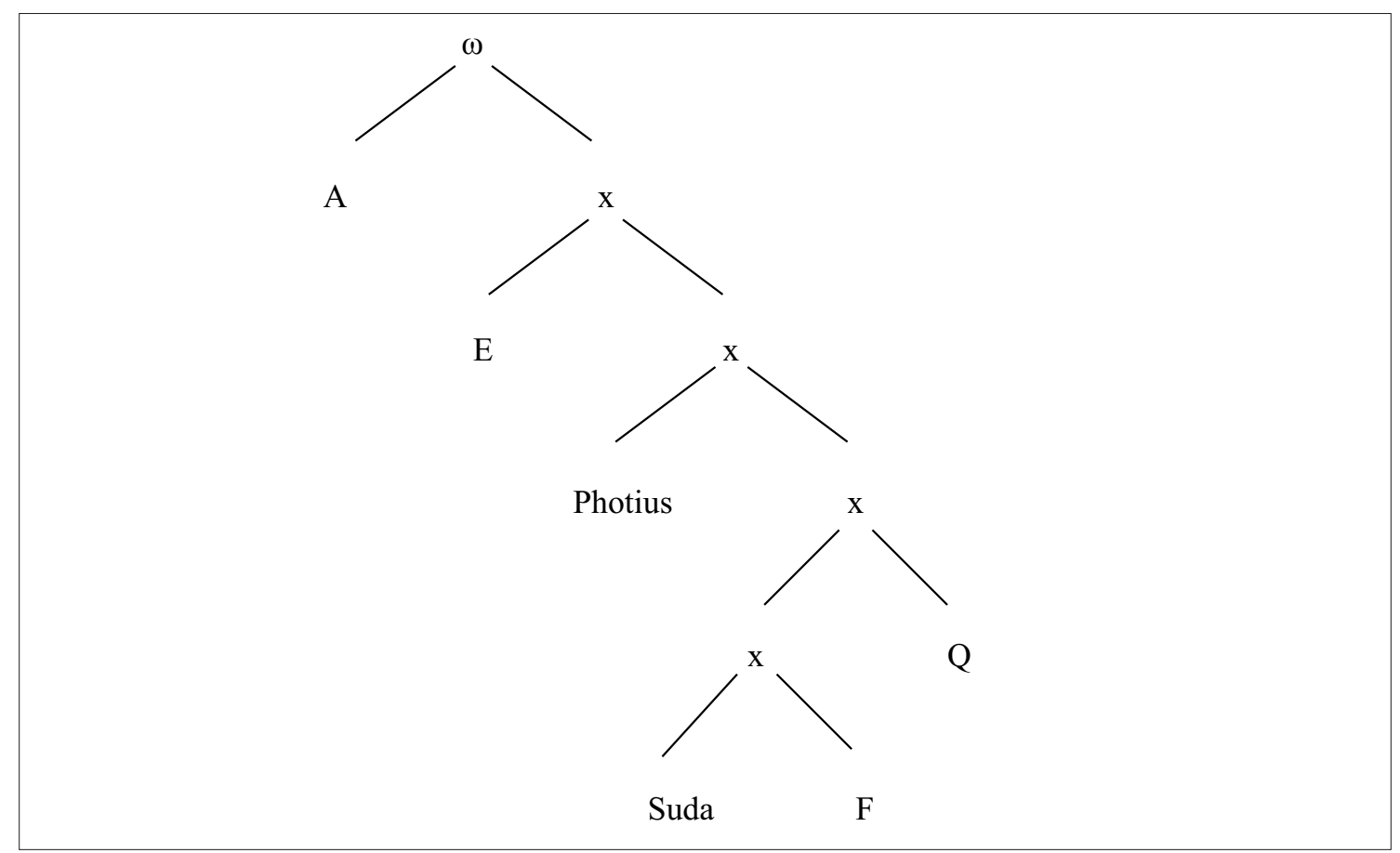

Fig. 1. Stemma of $V A$ (slightly simplified).

${ }^{21}$ One of this journal's anonymous reviewers remarks: ' $\dot{\varepsilon} \zeta$ in the encomiastic context seems to rely on the idea of presence, whether real (in the case of the emperors and the Gorgias title) or imagined (in the case of the Homeric hymns, where the god is certainly envisaged as being in the vicinity of the speaker). In other words, the primary meaning is "addressed to", which then takes on an encomiastic tinge. Clearly Philostratus' text is not addressed to Apollonius in this way'. I fully agree, but even so I think that this does not undermine my thesis. For one thing, I do not contend that the title is meant as indicating a hymn tout court. I contend that the title is partly inspired by the titles of hymns, namely by borrowing the encomiastic element which is characteristic of hymns. For another I would refer to $V A 6.39$, the story about the man who found an enormous treasure in the land he had bought, while following Apollonius' advice; the man is overwhelmed with joy and conse-

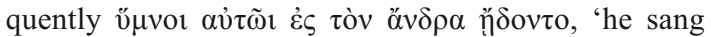
hymns in praise of him [= Apollonius]'. Here we need neither assume that Apollonius himself was present when the man sung his praise nor that his presence was evoked.

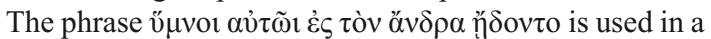
loose sense. And this is the case with the use of eis in the title of the work too.

${ }^{22}$ For the ambiguity of $V A$ and its title, see above, with n.6.

23 The same ambiguity appears to be present in 1.3.2.

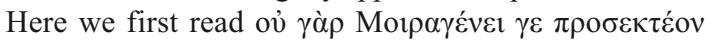

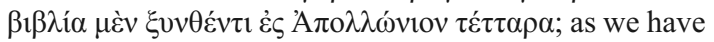
already seen (n.20), Jones argues that here the meaning of $\dot{\varepsilon} \zeta$ is simply 'about'. A few lines further, however, we

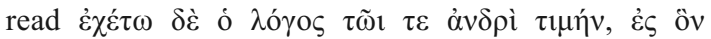

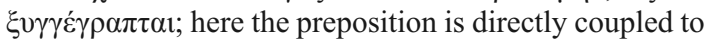
the concept of $\tau \mu \mu$, 'honour'. 


\section{Bibliography}

Anderson, G. (1986) Philostratus: Biography and Belles Lettres in the Third Century AD (London)

Baldelli, F. (1549) Della vita di Apollonio Tianeo (Florence)

Billault, A. (2000) L'univers de Philostrate (Brussels)

Boter, G.J. (2009) 'Towards a new critical edition of Philostratus' Life of Apollonius: the affiliation of the manuscripts', in K. Demoen and D. Praet (eds), Theios Sophistes (Leiden and Boston) 21-56

- (2014) 'Studies in the textual tradition of Philostratus' Life of Apollonius of Tyana', RHT n.s. 9, 1-49

Bowie, E.L. (1978) 'Apollonius of Tyana: tradition and reality', ANRW 2.16.2, 1652-99

- (1994) 'Philostratus: writer of fiction', in J.R. Morgan and R. Stoneman (eds), Greek Fiction: the Greek Novel in Context (London and New York) 181-99

Conybeare, F.C. (1912) Philostratus, The Life of Apollonius of Tyana. The Epistles of Apollonius and the Treatise of Eusebius (Cambridge MA)

del Corno, D. (1978) Filostrato, Vita di Apollonio di Tiana (Milan)

des Places, E. (1986) Eusèbe de Césarée, Contre Hiéroclès (Paris)

de Vigenère, B. (1611) De la vie d'Apollonius Thyaneen (Paris)

Flinterman, J.J. (2009) “"The ancestor of my wisdom": Pythagoras and Pythagoreanism in Life of Apollonius', in E. Bowie and J. Elsner (eds), Philostratus (Cambridge) 155-75

Francis, J.A. (1998) 'Truthful fiction: new questions to old answers on Philostratus' Life of Apollonius', AJPh 119, 419-41

Gyselinck, W. (2008) Talis oratio, qualis vita. Een tekstpragmatisch onderzoek naar de poëtica van Flavius Philostratus' Vita Apollonii (Ph.D. Diss. University Ghent), accessible at http://lib.ugent.be/fulltxt/ RUG01/001/376/207/RUG01-001376207_2010_0001_AC.pdf (accessed 24 June 2015)

Hägg, T. (2004) 'Apollonius of Tyana - magician, philosopher, counter-Christ. The metamorphosis of a life', in L.B. Mortensen and T. Eide (eds), Parthenope. Selected Studies in Ancient Greek Fiction (19692004) (Copenhagen) 379-404

- (2012) The Art of Biography in Antiquity (Cambridge)

Jones, C.P. (2005) Philostratus, The Life of Apollonius of Tyana, Books I-IV (Cambridge MA)

Kayser, C.L. (1844) Flavii Philostrati quae supersunt. Philostrati junioris Imagines. Callistrati Descriptiones (Zurich)

- (1870-1871) Flavii Philostrati opera, I-II (Leipzig)

Keulen, W. (2006) 'Narrativa "di confine", in L. Graverini, W. Keulen and A. Barchiesi (eds), Il romanzo antico: forme, testi, problemi (Rome) 179-92

Manutius, A. (1501-1502) Philostrati de uita Apollonii Tyanei libri octo (Venice)

Morel, F. (1608) Philostratii Lemnii opera quae extant, Philostrati junioris imagines, et Callistrati ecphrases. Item Eusebii Caesariensis episcopi liber contra Hieroclem (Paris)

Mumprecht, V. (1983) Flavius Philostratus, Das Leben des Apollonius von Tyana (Munich)

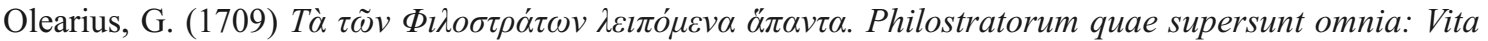
Apollonii libris VIII. Vitae sophistarum libris II. Heroica. Imagines priores atque posteriores et epistolae. Accessere Apollonii Tyanensis Epistolae, Eusebii Liber adversus Hieroclem, Callistrati Descript. statuarum (Leipzig)

Phillimore, J.S. (1912) Philostratus, In Honour of Apollonius of Tyana (Oxford)

Reardon, B.P. (1971) Courants littéraires grecs des IIe et IIIe siècles après J.-C. (Paris)

- (2004) Chariton Aphrodisiensis, De Callirhoe narrationes amatoriae (Munich and Leipzig)

Robiano, P. (2001) 'Un discours encomiastique : en l'honneur d'Apollonios de Tyane', REG 114, 637-46

Swain, A. (1999) 'Defending Hellenism: Philostratus, In honour of Apollonius', in M. Edwards, M. Goodman and S. Price (eds), Apologetics in the Roman Empire (Oxford), 157-96

Westermann, A. (1849) Philostratorum et Callistrati opera (Paris)

Whitmarsh, T. (2001) Greek Literature and the Roman Empire: The Politics of Imitation (Oxford) 